\title{
Influence of Relational Experience on Customer Satisfaction Among Mobile Phone Users in Selected Public Universities in Kenya
}

\author{
Dr. Kennedy Ntabo Otiso (PhD) \\ Senior Lecturer, \\ School of Business, Department of Business Administration and Management Science, \\ Koitaleel Samoei University College, \\ (A constituent College of the University of Nairobi), \\ P.O. Box 5-30307- Mosoriot, Kenya
}

\begin{abstract}
The study focused on the influence of relational experience on customer satisfaction. The study was guided by the social exchange theory which focused on the fundamental principle that humans in social situations choose behaviors that maximize their likelihood of meeting self-interests in those situations. Descriptive and explanatory research designs were utilized in this study and the following networks were sampled; Safaricom, Airtel,Orange and, yuMobile A questionnaire was used to collect data from sample size of 250 respondents who were sampled from the staff of public universities in the Western region which included Moi, Masinde Muliro, Maseno, Jaramogi Oginga Odinga, University of Eldoret and Kisii University. Data collected was analyzed by use of descriptive and inferential statistics.Multiple regressions were used to establish the effect between customer relationship management practices, customer satisfaction and customer Retention. The results revealed that Customer relational experience had significant effect on Customer retention. Further,Customer relational experience had significant effect on Customer satisfaction. Also it was established that, Customer satisfaction was significant in predicting customer retention. The study recommends that service providers should put more emphasis on Customer Relationship Management Practices since they influence customer satisfaction and hence customer retention.
\end{abstract}

Keywords: Relational Experience, customer, customer satisfaction, retention

DOI: $10.7176 / \mathrm{EJBM} / 13-20-11$

Publication date:October $31^{\text {st }} 2021$

\section{Background information}

Organizations both private and public in today's dynamic market place are increasingly leaving anticipated marketing philosophies and strategies to the adoption of more customer-driven initiatives that seeks to understand, attract, retain and build long term relationship with profitable customers (Kotler, 2006,Gronroos,C 1994). This paradigm shift has undauntedly led to the growing interest in CRM practices that aim at ensuring customer identification, interactions, customization and personalization that unreservedly lead to customer satisfaction, retention and profitability (Thompson, 2004, Gronroos et al., 1996; Xu et al, 2002, store, 2000). CRM practices is defined as, "activities that focuses on managing the relationship between a firm and its current and prospective customer base, as a key to success, (Gebert, 2003). It further, means developing a comprehensive picture of customer needs, expectations and behaviors and managing those factors to affect business performance. CRM practices help in building long lasting relationships and these relationships give a company joy of retained customers. Customer satisfaction is one of the most areas being researched in many service studies due to its importance in determining the success and the continued existence of the service business (Gursoy et al., 2007). Customer satisfaction conceptually has been defined as feeling of the post utilization that the consumers experience from their purchase (Westbrook and Oliver, 1991; Um et al., 2006). Opposite to cognitive focus of perceptions, customer satisfaction is deemed as affective response to a products or services (Yuan et al., 2005). A consumer is deemed to be satisfied upon the experience weighted sum total produce a feeling of enjoyment when compared with the expectation (Choi and Chu, 2001). In service studies, customer satisfaction is the customers' state of emotion after experiencing the service (Baker and Crompton, 2000; Sanchez et al., 2006). Customer satisfaction is the extent of overall enjoyment that customer feel, the result that the service experience able to fulfill the customer desires, expectation, needs and wants from the service (Chen and Tsai, 2007). Taylor et al., (2004) pointed out that customer satisfaction has a direct influence on customer loyalty. Kotler (2008) describes customer satisfaction is the feeling of happiness or unhappiness as a result of comparing the perceived performance of services or products with the expected performance. If the perceived performance does not meet the expected performance, then the customer will feel disappointed or dissatisfied. Homburg et al. (2008) suggested that customer satisfaction has been a crucial issue in marketing field in the past decades since satisfied customers are able to offer to the company such as customer loyalty and continuous profitability. 


\section{LITERATURE REVIEW}

\section{Concept of Customer Satisfaction}

Customer satisfaction is perceived as a relative judgment that considers the qualities versus the cost and efforts obtained through a purchase (Ostrom and Lacobucci, 1995).Customer satisfaction is considered as important outcome of a buyer-seller interaction (Roos et al.., 2006; Smith and Barclay, 1997). The literature contains two general conceptualizations of customer satisfaction: transaction-specific satisfaction and cumulative satisfaction (Bolton and Drew, 1991; Cronin and Taylor, 1994; Shankar et al., 2003). While transaction-specific satisfaction may provide specific diagnostic information regarding a specific product or service encounter, cumulative satisfaction resulting from a series of transactions or service encounter is a more fundamental indicator of a firm's past, current and future performance (Anderson et al., 1997; Lam et al., 2004; Oliver,1997). Therefore this study focuses on cumulative satisfaction and defines satisfaction as the emotional state developed from a relationship that resulted from customer interactions over time.

The notion of customer satisfaction is part of a wider focus on building total customer value, which can be defined as: "the perceived monetary value of the bundle of economic, functional and psychological benefits customers expect from a given market offering" (Kotler and Keller, 2009). Zeithaml and Bitner (2000), define customer satisfaction as follows: "Satisfaction is the customer evaluation of a product or service in terms of whether that product or service has met their needs and expectations.

Customer satisfaction has been fundamental to the marketing concept for over three decades (Parker and Mathews, 2001). It is widely recognized in the good and service sectors that customer satisfaction as the main performance indicator and the key to success for any business organization (Mihelis, Grigoroudis, Siskos, Politis, and Malandrakis, 2001). However, the intangible nature of customer satisfaction make the term hard to measure. Therefore, many researchers attempt to discover the antecedents and consequences of customer satisfaction in order to provide a better understanding of customer, increase market share and profitability, reduce cost and enhance product or service performance as well as internal quality control (Anderson and Sullivan, 1993; Ndubisi and Chan, 2005). Sprowls and Asimow (1962) contrasted and discussed customer behavior model and reported that customer satisfaction result in repeated purchase and emphasize the importance of customer satisfaction for the organization. In early 1970s, Anderson (1973) and Olshavask and Miller (1972) investigated customer satisfaction based on the expectation and perceived product performance. Churchill and Suprenant (1982) study identify the antecedent and construct measurement of customer satisfaction based on disconfirmation paradigm. Previous studies define customer satisfaction as "disconfirmation paradigm" (Churchill and Suprenant, 1982), which is a result of confirmation/disconfirmation of expectations that compare product (or service) performance with their expectations and desire (Spreng, MacKenzie, and Olshavsky, 1996). Boulding, Kalra, Staelin, and Zeithaml (1993) conceptualized customer satisfaction into transaction specific and cumulative (Anderson, Fornell and Lehmann, 1994). The transaction specific viewed customer satisfaction as evaluative judgement after a specific buying process (Hunt 1977; Oliver, 1993). However, cumulative customers' satisfaction emphasizes more on the total evaluation based on total consumption over time (Johnson and Fornell 1991; Fornell 1992). Other researchers consider the term customer satisfaction as an attitude or evaluation formed by customers who compares pre-purchase expectations about the outcome of a product or service from the actual performance they received (Oliver, 1980; Fornell, 1992).

According to Hoyer and MaClnnis (1997), consumers measure their experiences of a product or service after acquisition, consumption and disposition. Customer satisfaction / dissatisfaction require experience with the product which depends on the quality and value of the service (Anderson et al., 1994). Any discrepancy may cause disconfirmation (Hoyer et al, 997), thus, failure to meet the needs and expectations is assumed to result in dissatisfaction with the product or service". Hoyer and MaClnnis (1997), argued that a favourable outcome means they are satisfied whilst an unfavourable outcome results in dissatisfaction. The conceptual relationship between customer satisfaction and service quality has generated mixed results among researchers. Anderson et al. (1994) point out a distinction between customer satisfaction and future experience a customer gets when he comes into contact with a product or service and value received. Recent studies have also pointed out that service quality is an antecedent of customer satisfaction (Anderson and Sullivan, 1993; Cronin and Taylor, 1992). There is however, consensus that further studies would have to be done on this issue. Satisfaction is based on the customer's previous experiences with the service provider, advice of friends and associates, competitors offering and information from marketers (Kotler, 1997). It has also been argued that satisfaction/dissatisfaction with a product or pleasure will lead to satisfaction. In contrast, negative emotions such as grief, sadness, distress, sorrow, regret, disappointment, anger, agitation, will engender dissatisfaction (Zeithaml and Bitner, 2000; Hoyer and MaClnnis, 1997). Services are influenced by customers' state of mind and emotions, even Positive feelings such as happiness, excitement.

Customers stay longer in consuming company services due to a developed sense of security and loyalty brought about by the satisfaction and they deepen their relationship with the company. Customers will also demonstrate less price sensitivity, due to the fact that the products and services provided exceed the customers' expectations and thus raising the individual switching costs. Customers tell and recommend company product or 
service. Satisfied customers tend to tell others of the benefits of the products and services received, thus marketing the organizations products and services. Theoretically, service attributes can be considered as a cognition-based construct, while customer satisfaction is mainly an effective and evaluative response (Oliver, 1993).

Social science literature indicates that cognitive thought processes trigger affective responses (Weiner, 1996), suggesting that customer assessments of service attributes affect their satisfaction attitude. That is, the degree to which suppliers could meet the requirements of customers influenced the strength of the customers' positive attitude toward the service providers (Turnbull and Moustakatos, 1996). Customer satisfaction is a complex construct and has been defined in various ways (Besterfield, 1994; Barsky, 1995; Kanji and Moura, 2002; Fecikova, 2004). Recently, researchers have argued that there is a distinction between customer satisfactions as related to service experiences. The distinction is due to the inherent intangibility and perishability of services, as well as the inability to separate production and consumption. Hence, customer satisfaction with services and with goods may derive from, and may be influenced by, different factors and therefore should be treated as separate and distinct (Veloutsou et al, 2005).

Research has shown that it cost between five to six times more to attract a new customer than to keep an existing customer. Companies can also boost profits anywhere from $25 \%$ to $125 \%$ by retaining merely $5 \%$ more existing customer and also that happy customers will tell to others of their positive experience, whereas dissatisfied customers tell 9 to 12 how bad it was. It is also assumed that Only one out of 25 dissatisfied customers will express dissatisfaction and Two third of customers do no feel valued by those serving them.(Adapted from Gary Luck, The Ash ridge journal, Customer Satisfaction Strategy, autumn (2006).

The customers will have expectations that relate to the company branches and offices that they visit their staff and deal with the organization as all customers' needs and wants change over time and thus the organization seeking to satisfy these needs has to be dynamic and responsive to the customer's expectations. Schneider and Bowen (1995) assert that "service organizations must meet three key customer needs to deliver service excellence," Security, esteem and justice. They also identified an array of service quality factors that are important for customers including timeliness and convenience, personal attention, reliability and dependability, employee competence and professionalism, empathy, responsiveness, assurance, and availability and tangibles such as physical facilities and equipment and the appearance of personnel.

Customer satisfaction holds the potential for increasing the organizations customer base, increase the use of more volatile customer mix and increase the firm's reputation, (Fornell1992, Levesque and Mc Daugall, 1999). This means that firms in the mobile industry should satisfy their customers so that they can become loyal and remain with them. Marketing theory and practice suggest that mobile phone firms should improve their service by satisfying their customers, so as to obtain and sustain advantage in the intensely competitive business environment. This is because the main output of customer satisfaction is customer loyalty, and a firm with bigger share of loyal customers, profit from increased repurchase rate, greater cross buying potential, higher price willingness, positive recommendation behavior and lower switching tendencies. Furthermore, long term customers tend to take less of company time and are sometimes less sensitive to the price, Gan et al (2006). They further indicate that retaining customers become the priority for most enterprises and there is compelling arguments for managers to carefully consider the factors that might increase customer retention rate. In any case, the cost of creating a new customer has been estimated to be five times the cost of retaining existing customers, (Reichheld 1996). A retained customer will always show resistance to competitors' enticement and will be able to give both solicited and unsolicited referral (Omotayo et al, 2008). Customer retention is, therefore, crucial to mobile cellular companies; because improvement in customer retention can cause an increase in profitability; depending upon the industry (Reichheld and Sasser, 1990). The mobile telephone industry has undergone rapid changes in the recent years. The deregulation of the industry has caused a lot of service providers to enter the industry hence increasing the competition in the industry. The competition in the industry can be described as fierce and stiff.

The cellular phone companies are, therefore, doing everything possible to attract new customers and retain the existing ones. Service quality has, therefore, become very crucial for the service providers in the retention of their customers. In recent times, subscribers have complained vehemently on the quality of services provided by service providers. A substantial number of customers of mobile telephones have taken service providers to task for rendering unsatisfactory services. However, there is little empirical research undertaken, as far as can be ascertained on how quality service leads to customer retention in the mobile telephony industry. The study aims at investigating whether a service provider in general is doing what customers perceive as quality service to improve customer retention. The study is undertaken to clarify certain questions related to customer retention in the mobile telephone Industry.

\section{Customer Relational Experience and Customer Satisfaction}

The consumer's satisfaction or dissatisfaction is consequences of consumption or service experiences (Janiszewski, 2009). The process of consumer behavior describe the basic step that an ultimate consumer goes through in satisfying what customer want in the market which is problem recognition to information search and choice and 
post decision evaluation (Pine and Gilmore, 1990). Customer retention is based on experiences in the interpretation of the exchange relationship in the marketplace. The ongoing buyer seller relationships take many different forms. The buyer's perception of the effectiveness of the exchange relationship is a significant mobility barrier and potential competitive advantage for the seller that insulates from price competition.

Relationship Quality emerged from the field of Relationship Marketing (RM). Due to the importance of relationship marketing in today's businesses, relationship quality is essential for assessment of relationship strength and the satisfied degree of customer needs and expectations (Crosby and Evans and Cowles, 1990; Smith, 1998). Successful exchange events can finally lead to an enduring buyer-seller relationship if they are properly treated from both a buyer and a seller's perspectives (Crosby et al., 1990). In some service contexts, since service is invisible and heterogeneous, customers would feel high uncertainty and risk in the transaction (Li and Ho, 2008). Whereas, good relationship quality could reduce service uncertainty and risk for the purpose of increasing customers' reliability to develop long-term relationships (Crosby et al., 1990; Li and Ho, 2008). In other words, higher quality of relationship creates association between service providers and customers, and fosters long-term stable exchanges where both parties can gain mutual benefits (Singh, 2008).

Relationship quality does not have a widely accepted definition and measures (Singh, 2008). Various dimensions have been put forward to measure relationship quality within marketing researches. One attempt to conceptualize relationship quality has been proposed by Grosbyetal. (1990), who viewed relationship quality as a high-order construct and should contain at least two dimensions: trust and satisfaction. Morgan and Hunt (1994) drew commitment-trust theory by proposing that trust and commitment are two basic constructs for measuring relationship quality. By integrating different research viewpoint, Chakrabarty, Whitten and Green (2007) discussed that relationship quality is measured in terms of trust, commitment, culture, interdependence, and communication. Otherwise, Lages et al. (2005), from a perspective of business organization rather than consumers, suggested that relationship quality reflected the intensity of information sharing, communication quality, long-term orientation and satisfaction with the relationship between the exporter and importer. Although there are no consensuses regarding the components that form up relationship quality, it is generally accepted that trust and satisfaction are two significant factors for measuring relationship quality. Especially in the context of service markets, high relationship quality perceived by customers is achieved through customer trusts and customer satisfaction, which are two key points for service providers to consolidate stable long-term relationship with their customers, and in turn achieve customer retention and loyalty behavior. Therefore, we study relationship quality by focusing on trust and satisfaction from customers' perspectives.

\section{RESEARCH METHODOLOGY}

\section{Research Philosophy}

In this study positivism was chosen more than phenomenological perspective because we believe that customer retention as pertaining mobile phone service users can be defined objectively through the use of established theoretical frameworks and structured instruments to assess and analyze it, upon which generalizations can be made from the findings.

\section{Research Purpose}

The research purpose is abroad statement of what the research hopes to achieve. According to purpose, research could be broadly divided into exploratory, descriptive and explanatory (Saunders et al 2000, 2007; Cooper and Schindler 2006). An explanatory research is a study that is conducted to "find out what is happening, to seek new insights, to ask questions and to assess phenomena in a new light" (Robson2002:59). It is mainly used when a researcher wants to have a clearer understanding of a situation or a problem, where the area of study is so new or vague, important variable may be known or defined. It therefore uses such methods as searching documented materials, asking for expert's opinion, and conducting a focus group interviews.

A descriptive research is a study that seeks to "portray an accurate profile of persons, events or situations" (Robson 2002:59 in Saunders et al 2007). It involves formalizing the study with definite structures in order to better describe or present facts about a phenomenon as it is perceived or as it is in reality.

An explanatory research is a study that seeks to establish relationship that exists between variables. In other words, its purpose is to identify how one variable affects the other; it seeks to provide an explanation to the causes and/ or effects of one or more variables (Saunders et al 2000, 2007; Cooper and Schindler 2006, Malhotra and Birks, 2007). It is often termed as causal studies. They are also used when the purpose of the study is to answer "why" in a given context. This study had significant combination of both the two: Descriptive and explanatory purposes.

\subsubsection{Time Horizon}

According to time horizon, research design can be longitudinal or cross-sectional. Across- sectional study focuses on a particular phenomenon at a specified period of time (Saunders et al 2007). In this case, one sample of a population can be taken and studied at particular time as in a single cross-sectional study or two or more samples 
of a target population could be studied once as in multiple cross sectional study (Malhotra and Birks 2007). This study chose a cross-sectional study because data was collected from a cross section of Mobile phone service users once and not for different periods of time.

\subsubsection{Research Strategy}

Research Strategy is a general plan of how to answer the research questions. It is mainly guided by the research questions and research objectives, among other things. It determines to a large extent the choice of data collection methods. The main research strategies are action research, ethnographic studies, experiments, surveys, case study, grounded theory or archival research (Saunders et al 2000, 2007; Cooper and Schindler 2006;Malhotra and Birks 2007).

This study chose basically the survey strategy because it sought the opinion of a population about a specific subject matter and it combined the use of qualitative and quantitative methods

\subsection{Target Population}

The target population for the study was the users of Mobile Phone services and enjoying the use of Customer Relationship Management practices. Burns and Groove (1997) argues that a target population is the entire aggregation of respondents that meets designated set of criteria. The Target population of the study consisted of staff in public universities' in Western Kenya Region. The study defined Western Kenya as the region covering North Rift, former Nyanza province and former Western province. The public universities in the Western region included Moi, Masinde Muliro, Maseno, Jaramogi Oginga Odinga, University of Eldoret, Kisii University as at June, 2014. The staff in these Universities was characterized by grade, gender, working experience, level of education, and level of mobile phone exposure. The study targeted a population of 15007 which was indicated in official records in the payrolls of respective universities. The following is how the 15007 was arrived as a target population for this study;

\section{Table 3.1. Target Population}

\begin{tabular}{ll}
\hline Strata & Target Population \\
\hline Moi University & 6,900 \\
Maseno University & 2,500 \\
Masinde Muliro University of Science and Tech. & 1,400 \\
Jaramogi Oginga Odinga University & 2,070 \\
Kisii University & 837 \\
University of Eldoret & 1300 \\
TOTAL & $\mathbf{1 5 0 0 7}$ \\
\hline
\end{tabular}

\section{Source: Survey Data}

\subsection{Sampling}

The process of sampling involves any procedures using a small number of items or parts of the entire population to make conclusions regarding the whole population

\section{Sample size}

The sample size of each stratum in stratified random technique will be proportionate to the population size of the stratum when viewed against the entire population. This means that each stratum (each University) has the same sampling fraction (Castillo, 2009). The simple random sampling or probability sampling was used so that each and every one in the target population had an equal chance of inclusion. The sample size of Universities in each stratum and the number of respondents was obtained using coefficient of variation. Nassiuma (2000) asserts that in most surveys or experiments, a coefficient of variation in the range of $21 \%$ to $30 \%$ and a standard error in the range $2 \%$ to $5 \%$ is usually acceptable. The Nassiuma's formula does not assume any probability distribution and is a stable measure of variability. Therefore, a coefficient variation of $30 \%$ and a standard error of $2 \%$ were used in this study. The upper limit for coefficient of variation and standard error will be selected so as to ensure low variability in the sample and minimize the degree or error.

The formula will be;

$\mathrm{S}=\quad \mathrm{N}(\mathrm{CV})^{2}$

$$
(\mathrm{CV})^{2}+(\mathrm{N}-1) \mathrm{e}^{2}
$$

where $\mathrm{S}=$ the sample size

$\mathrm{N}=$ the population size

$\mathrm{Cv}=$ the Coefficient of Variation

$\mathrm{e}=$ standard error

Therefore, the sample size of Universities will be as indicated in the table below;

$$
=\frac{15007\left(0.3^{2}\right)}{0.3^{2+} 15007-(0.02)^{2}}=250
$$


Table 3.1: Sampling Frame of the Public Universities in Western Kenya Region

\begin{tabular}{lll}
\hline Name of University & Total Population & Sample Size \\
\hline Moi University & 6,900 & 102 \\
Maseno University & 2,500 & 36 \\
Masinde Muliro University of Science and Tech. & 1,400 & 20 \\
Jaramogi Oginga Odinga University & 2,070 & 30 \\
Kisii University & 837 & 13 \\
University of Eldoret & 1300 & 20 \\
TOTAL & $\mathbf{1 5 0 0 7}$ & $\mathbf{2 5 0}$ \\
\hline
\end{tabular}

Source: Survey Data, 2014

\section{Data Collection Instrument}

The questionnaire was used as the data collection instruments to enable achieve the stated objectives. The instrument was appropriate as it helped in collecting the primary data. The questionnaire was designed based on the five point likert-type scales. This was so because it was to enable answer specific research questions and help achieve the objectives of the study. Closed ended questions were used as they were deemed to motivate the respondents and save time.

\section{Reliability of study measures}

Reliability refers to whether a measurement instrument is able to yield consistent results each time it is applied. In order to test for reliability, Cronbach alpha coefficient was used since was the common method used for assessing reliability for a measurement scale with multi-point items. The reliability of the study measures was assessed by Cronbach's Alpha coefficient, which was used to assess the internal consistency or homogeneity among the research instrument items (Sekaran, 1992). The coefficient that reflects homogeneity among a set of items varies from 0 to 1. A good reliability should produce at least a coefficient value of 0.70 (Hair et al., 1995) but coefficients up to 0.62 are acceptable in social research studies (Kritsonis and Hurton, 2008). For this research the reliability coefficients met the criteria since all the reliability coefficients of the study variables were above 0.7 . The concepts of validity and reliability require the researcher to ensure data is gathered and treated in a manner that will not include change to interpretation. This means there is need to record the problem of the study as closely as possible (Creswell, 2003). However there is no absolute reliability in undertaking a research. The use of questionnaires is one source of bias because of literacy problems which may be present in the target respondents.

\section{Validity}

Validity refers to whether the statistical instrument measure what it is intended to measure, i.e. accuracy of measurement (Sullivan T.J. 2001; Saunders et al., 2000;2007). Validity is concerned with whether the findings are really what they appear to be about. This study will address the four approaches to establishing validity; face validity, content validity, criterion validity and construct validity (Zikmund et al., 2010). Face validity was established by inspecting the contents being studied for their appropriateness to logically appear to reflect what was to be measured further, face validity involves assessing whether a logical relationship exist between the variables and the proposed measure.

To establish content validity this research was validated by determining the variables which have been defined and used in literature previously. Additionally, opinions from experts were sought to provide relevant inputs adding to what had been identified from the literature. Piloting a questionnaire was crucial and had highlighted ambiguities and other potential pitfalls (Somekh and Lewin, 2005). The pilot study was carried out in Egerton University. Feedback from the pilot study enabled the researcher to make changes where necessary to the questionnaire. In addition, the respondents may have experienced boredom because the questions may seem monotonous and towards the end of the questionnaire, the respondent may not pay keen attention to details of the question. Yet another bias that may be experienced in the course of this research is acquiescence. This issue may arise when the respondent tends to agree with an issue whenever they are not sure or undecided. To overcome this possible bias, the study was to provide a short questionnaire. Reliability test was performed on the questionnaire items using Cronbach alpha. However the threshold that is acceptable in closely related researches is 0.7 and this is what will be the guide to this study (Eisenmerger et al, 1986).

\section{Ethical issues}

The major ethical concern which was considered important included; informed consent, confidentiality and privacy. The respondents were provided with adequate information concerning the study. The researcher explained to the respondents that participating in the study was voluntary and that they were free to withdraw from it at any time they deem fit.

Also clarity was provided on the nature of the research and procedures, and they were allowed to ask questions 
before, during and at the end of the study. No one was coerced to respond to the survey. The respondent were also guaranteed protection through anonymity and by keeping the information given confidential and if there was going to be need for disclosure their consent was sought. All the respondents were treated with respect and equality.

\section{DATA ANALYSIS, PRESENTATION AND INTERPRETATION}

\section{Response Rate}

The study intended to collect data from 250 respondents, but data was successfully collected from 222 respondents. This represents a response rate of 88.8 percent of the target population, which falls within the confines of a large sample size (Anderson, Sweeney and Williams, 2003)

\section{Profile of the Respondents}

The respondents' profiles of interest in this study were; Gender, Age of respondent, highest level of education, mobile phone service provider, and service provider used most and lengthy of time of usage of the services.

The total sample for the survey consists of 222 respondents. The gender distribution of the survey respondents is 65.3 per cent males and 34.7 per cent females. The results also indicated that the samples have age predominantly of 45 years and above, which is 46.4 per cent. More than 50 per cent of the respondents use Safaricom mobile phone service provider. Majority of the respondents have college or higher education level where 10.4 per cent are professional qualification, 13.5 per cent are diploma or advanced diploma holder, 16.2 per cent have degrees and 53.2 per cent have postgraduate level of education. Only 6.8 per cent of respondents have attained high-school level. The results are presented in Table 4.1

Table 4.1: Demographic Profile of Respondents

\begin{tabular}{|c|c|c|c|}
\hline \multicolumn{2}{|l|}{ Variables } & Frequency & Percentage \\
\hline \multirow[t]{2}{*}{ Gender } & Male & 145 & 65.3 \\
\hline & Female & 77 & 34.7 \\
\hline \multirow[t]{4}{*}{ Age } & $18-24$ & 20 & 9.0 \\
\hline & $25-34$ & 18 & 8.1 \\
\hline & $35-44$ & 81 & 36.5 \\
\hline & 45 and above & 103 & 46.4 \\
\hline \multirow[t]{5}{*}{ Level of Education } & O-Level & 15 & 6.8 \\
\hline & Certificate & 23 & 10.4 \\
\hline & Diploma & 30 & 13.5 \\
\hline & Bachelor's Degree & 36 & 16.2 \\
\hline & Post Graduate Degree & 118 & 53.2 \\
\hline \multirow[t]{4}{*}{ Mobile Service Provider } & Safaricom & 111 & 50 \\
\hline & Airtel & 80 & 36 \\
\hline & Orange & 28 & 12.6 \\
\hline & Yu-mobile & 3 & 1.4 \\
\hline \multirow{4}{*}{$\begin{array}{l}\text { Mobile Service Provider used } \\
\text { often }\end{array}$} & Safaricom & 104 & 46.8 \\
\hline & Airtel & 68 & 30.6 \\
\hline & Orange & 37 & 16.7 \\
\hline & Yu-mobile & 13 & 5.9 \\
\hline \multirow[t]{4}{*}{ Period of Usage } & $1-3$ years & 18 & 8.1 \\
\hline & 4-7 years & 91 & 41.0 \\
\hline & $8-10$ years & 82 & 36.9 \\
\hline & Over 11 years & 31 & 14.0 \\
\hline
\end{tabular}

Source: Research Data (2014)

\section{Descriptive Statistics}

For clear determination of the responses made to the research items, the mean, standard deviation, skewness and kurtosis of the study variables were determined as highlighted in Table 4.2

Table 4.2: Descriptive statistical analysis of the study variables

\begin{tabular}{lllll}
\hline Variables & Mean & Std dev & Skewness & Kurtosis \\
\hline CRE & 3.3468 & 0.66391 & -1.012 & 1.466 \\
CS & 3.4234 & 0.79292 & -0.583 & -0.248 \\
\hline
\end{tabular}

$\mathrm{CRE}=$ Customer Relational Experience, $\mathrm{CS}=$ Customer Satisfaction and

Source: Research Data (2014)

From Table 4.2 The Customer Relational Experience has a mean score of 3.3468 and a standard deviation of 0.66391 , it is skewed to the right with -1.012 and kurtosis of 1.466. Customer satisfaction is the mediator which has a mean of 3.4234 and a standard deviation of 0.79292 , its skeweness is -0.583 and its peakedness of -0.248 . 
Scale reliability of study Variables

The reliability of an instrument is defined as its ability to consistently measure the phenomenon it is designed to measure. The reliability of the questionnaire was therefore tested using Cronbach alpha measurements. From the table 4.3

Table 4.3. Cronbach's Alpha Reliability

\begin{tabular}{lll}
\hline Variables & Number of Items & Cronbach Alpha Coefficient \\
\hline CRE & $\mathbf{5}$ & 0.724 \\
CS & $\mathbf{4}$ & 0.722 \\
CRE $=$ Customer Relational Experience, CS=Customer Satisfaction & \\
\hline
\end{tabular}

Source: Research Data (2014).

The reliability coefficients (a) of each variable are as follows: Network quality (0.839); Perceived Value (0.808); Customer Relational Experience (0.724); Loyalty Programs (0.749); Customer satisfaction (0.722) and Customer retention (0.716). The reliability coefficients of most of the variables are above 0.70 , which concurs with the suggestion made by Nunnally (1978). The internal consistency was considered to be sufficient and adequate. As indicated in the above table Cronbach's alpha was computed separately for the study variables to enable assess the internal consistent among the study variable.

\section{Factor Analysis Results of Customer Relational Experience}

Results show that the 5 items for Relational Experience are sorted and clustered into two component. The KaiserMeyer-Olkin (KMO) measure of sampling adequacy and Barlett's Test of Sphericity were used. The KMO measure of sampling adequacy indicated a value of $(\mathrm{KMO}=0.631)$ indicating that the sample size was adequate for the variables entered into analysis. The Barlett's Test of Sphericity was significant $X^{2}=381.993, \mathrm{df}=10, \mathrm{p}<0.000$, implying that the factor analysis was appropriate for the study and there was relationship among variables for the Customer Relational Experience. The results show that the 5 items of Customer Relational Experience are sorted into two components. The results of the principal component analysis indicate that, there are two factors whose Eigenvalues exceed 1. The Eigenvalue of a factor represents the amount of total variance explained by that factor. For Customer Relational Experience, the first factor has Eigenvalue of 2.490 and the second factor has Eigenvalue of 1.331 , the two factors explain $76.430 \%$ of the total variance. The first factor explains $49.803 \%$ of this variance, while the second variable explained $26.627 \%$ of this variance. Varimax rotation tries to maximize the variance of each of the factor, so the total amount of variance accounted for the redistribution over the extracted factor. Principal component analysis with varimax rotation is widely adopted as a reliable method of factor analysis (Sinkkonnen, Malhotra and Galleta, 1999).

Table 4.7: Customer Relational Experience Rotated Component Matrix

\begin{tabular}{lll}
\hline Scale item & Factor Loadings & \\
\hline & 1 & 2 \\
Safety with service provider & .878 & \\
Employees are courteous & .808 & \\
Simple Procedures & .773 & .848 \\
Prior Information on planned activities provided & & .878 \\
Ease of making electronic credit transfers & & 1.331 \\
Notes: Eigenvalues & 2.490 & $26.627 \%$ \\
$\quad$ Percentage of Variance & $49.803 \%$ & \\
$\quad$ KMO Measure of sampling adequacy .630 & & \\
$\quad$ Approx. Chi-Square 381.993, Df 10, Sig .000 & & \\
Extraction Method: Principal component Analysis & & \\
Rotation Method: Varimax with Kaiser Normalization \\
Rotation converged in 3 iterations
\end{tabular}

Source: Research Data (2014)

\section{Factor Analysis Results of Customer Satisfaction}

The Kaiser-Meyer-Olkin (KMO) measure of sampling adequacy and Barlett's Test of Sphericity were used. The KMO measure of sampling adequacy indicated a value of $(\mathrm{KMO}=0.594)$ indicating that the sample size was adequate for the variables entered into analysis. The Barlett's Test of Sphericity was significant $X^{2}=307.448, \mathrm{df}=6$, $\mathrm{p}<0.000$, implying that the factor analysis was appropriate for the study and there was relationship among variables. The results of the principal component analysis indicate that, there are two factors whose Eigenvalues exceed 1. The Eigenvalue of a factor represents the amount of total variance explained by that factor. For Customer satisfaction, the first factor has Eigenvalue of 2.231 and explain $55.768 \%$ of the total variance and the second factor has Eigenvalue of 1.148 and explain 28.697 , the two factors explain $84.464 \%$ of the total variance. The first factor explains $55.768 \%$ of this variance, while the second variable explained $28.697 \%$ of this variance. Varimax 
rotation tries to maximize the variance of each of the factor, so the total amount of variance accounted for the redistribution over the extracted factor. Principal component analysis with varimax rotation is widely adopted as a reliable method of factor analysis (Sinkkonnen, Malhotra and Galleta, 1999).

\section{Table 4.9: Customer satisfaction Rotated Component Matrix}

\begin{tabular}{|c|c|c|}
\hline \multirow[t]{2}{*}{ Scale item } & & Factor Loadings \\
\hline & 1 & 2 \\
\hline Satisfied with this service provider's services & .909 & \\
\hline Service provider is successful & & .707 \\
\hline Service provider meets my expectations & .870 & \\
\hline Overall, service provider has met my expectations & .952 & \\
\hline Notes: Eigenvalues & 2.231 & 1.148 \\
\hline Percentage of Variance & $55.768 \%$ & $28.697 \%$ \\
\hline Measure of sampling adequacy .729 & & \\
\hline Approx. Chi-Square 307.448 , Df 6, Sig. .000 & & \\
\hline Extraction Method: Principal component Analysis & & \\
\hline Rotation Method: Varimax with Kaiser Normalization & & \\
\hline Rotation converged in 3 iterations & & \\
\hline
\end{tabular}

Source: Research Data (2014)

\section{Correlation Analysis}

The correlation shown in the table below presents bivariate correlations between variables. Since a single construct in the questionnaire was measured by multiple items, the average score of the multi-items for a construct was computed and used in further analysis such as correlation analysis and multiple regression analysis (Wang and Benbasat, 2007).

From the table attached, When the correlation coefficient value ( $\mathrm{r}$ ) range from $0.10-0.29$, is considered to be weak, 0.30-0.49, medium, 0.5-1.0 is considered strong, Wong \&Hiew (2005). According to Field (2005), correlation coefficient should not go beyond 0.8 to avoid Multicollinearity. In this research, the highest correlation coefficient is 0.69 , thereby implying that there was no multicollinearity problem in this research, since the value is less than 0.8 . CRE is positively and statistically significant $(\mathrm{r}=0.707, \mathrm{p}<0.00$ ( 2 tailed at $1 \%$ level of significance), $\mathrm{CS}$ is positively and statistically significant, $(\mathrm{r}=0.434, \mathrm{p}<0.00$ (2 tailed at $1 \%$ level of significance), the CRE was correlated to customer retention and were positively and statistically significant.

Table 4.11. Pearson Correlation Coefficient of Study Variable

\begin{tabular}{llllllll}
\hline & NQ & PV & CRE & LP & CS & CR & Sig. (2 tailed) \\
\hline NQ & 1 & & & & & & \\
PV & .516 & 1 & & & & & \\
CRE & .707 & .790 & 1 & & & & \\
LP & .723 & .542 & .673 & 1 & & \\
CS & .434 & .214 & .524 & .518 & 1 & & \\
CR & .501 & .461 & .512 & .587 & .646 & 1 &
\end{tabular}

$\mathrm{NQ}=$ Network Quality, $\mathrm{PV}=$ Perceived Value, $\mathrm{CRE}=$ Customer Relational Experience, LP=Loyalty Programs, $\mathrm{CS}=$ Customer Satisfaction and $\mathrm{CR}=$ Customer Retention

Source: Research Data (2014)

\section{SUMMARY OF FINDINGS, CONCLUSIONS AND RECOMMENDATIONS \\ Summary of findings \\ Effect of Customer Relational Experience on Customer Retention}

Hypothesis $\mathrm{Ho}_{3}$ pstulated that customer relational experience has no significant effect on customer retention. From the findings, it was indicated that Beta coefficients (Customer Relational Experience), $\beta=-0.531, \mathrm{t}=-3.388, \mathrm{p}=0.005$. The Null hypothesis was therefore rejected since its p-value is $<0.05$ and an alternative hypothesis was accepted, meaning that Customer relational experience had an effect on Customer Retention. This result supports prior researches that focused on Customer Relational Experience and Customer Retention, Further due to the importance of relationship marketing in today's businesses, relationship quality is essential for assessment of relationship strength and the satisfied degree of customer needs and expectations (Crosby and Evans and Cowles, 1990; Smith, 1998). Successful exchange events can finally lead to an enduring buyer-seller relationship if they are properly treated from both a buyer and a seller's perspectives (Crosby et al., 1990). In some service contexts, since service is invisible and heterogeneous, customers would feel high uncertainty and risk in the transaction (Li and Ho, 2008). Whereas, good relationship quality could reduce service uncertainty and risk for the purpose of increasing customers' reliability to develop long-term relationships (Crosby et al., 1990; Li and Ho, 2008). In other words, higher quality of relationship creates association between service providers and customers, and fosters long-term 
stable exchanges where both parties can gain mutual benefits (Singh, 2008). This is further supported by Chakrabarty, Whitten and Green (2007) who discussed that relationship quality is measured in terms of trust, commitment, culture, interdependence, and communication. Otherwise, Lages et al. (2005), from a perspective of business organization rather than consumers, suggested that relationship quality reflected the intensity of information sharing, communication quality, long-term orientation and satisfaction with the relationship.

This study identified the number of customers, or percentage of total customers whose experience with their telecommunication service provider's products or services meets or exceeds their expectations. In a competitive market place where businesses compete for customers, customer satisfaction is seen as a key differentiator and increasingly has become a key element of business strategy. According to the study, Customer satisfaction is about how products and services meets consumer's needs. It is the impression of customers about services provided. Therefore, from the findings, customer relationship management practices have become an alternative means for organizations to build strong, ongoing associations with their customers.

Again from the research, as part of marketing strategy, customer relationship management practices seeks to acquire and retain customers by providing good quality customer services, and therefore has become one of the keys to success in acquiring strong competitiveness in the present markets, because of its implications for access to markets, generation of repeat purchase, creation of exit barriers, and the view that it benefits all parties (Andaleeb, 1996). It is concluded that Customer Relationship management Practices is concerned about building customer satisfaction by providing value to all the parties involved in the relational exchanges (Peng and Wang, 2006), as customer retention is the final goal of relationship marketing.

In conclusion, customer relationship management practices in today's business, it make sense to understand how the relationship are executed in practice and how this type of marketing take effect, e.g. influencing longterm relationship building and customer loyalty. As more and more enterprises realize the importance of becoming customer centric in today's competitive economy, they embrace Customer Relationship Management (CRM) as core business strategy" (Wu, 2008). Where CRM is a way of "developing a comprehensive picture of customers' needs, expectation and behaviors and managing those factors to affect business performance" (Hoots 2005). Or it is "about managing customer knowledge to better understanding and serving them"(Rahimi 2008).

In conclusion, the findings of this study have important implications for both academic marketing literature and practice. The managers will also find some useful implications that are relevant and can be applied in designing an appropriate CRM Practices for their customers.

In general, this study looked at the mediation effect of customer satisfaction on the relationship between CRM Practices and customer satisfaction amongst mobile phone users in western Kenya Region. In particular, the study examined the relationships between the study variables. All the relationships were significant and partially mediated. It is evident that from the study CRM practices emphasized in the trading relationships, will lead to repeated purchases hence consumer retention. This also enables Mobile phone service providers to ensure that the greater the customer satisfaction, the higher the consumer retention levels.

The study concluded that, the quality of a service is subjectively perceived by customers during the interactions with a Mobile phone service providers has critical impact on customers' evaluation of service quality. Effective communication of pricing policies as well as flexible pricing for various services offered play a great role in customer retention. The study concluded that since highly satisfied customers are expected to make future purchases and recommend the source to other customers, high levels of customer satisfaction are likely to lead to customer retention. The study also concluded that there exist very high levels of customer satisfaction Mobile phone service providers. Customer satisfaction was found to have a direct relationship with customer retention. Thus, when customers are satisfied with the services offered them by mobile network operators, they are likely to be loyal to them. Finally, the study found that Reliability has a direct effect on customer retention without necessarily using customer satisfaction as a conduit. The implication of this finding is that customers place a high premium on reliable Mobile phone service providers in western Kenya region.

The study recommends that mobile telecommunication operators who are interested in building brand loyalty should endeavor to satisfy their customer through the provision of enhanced mobile services. Additionally, the study recommends that in order to increase customer Satisfaction, it is essential for service firms to actively manage their customers' price perceptions. The study recommends that operators offer something valuable to customers in service interaction process, such as reward and promotional offers, in order to gain customer satisfaction, which is expected to enhance customer retention.

Moreover, the study recommends that companies must focus on those attributes of customer satisfaction which consumers' base on to judge the retention of the services offered. Additionally, the study recommends that firms should commit or embrace CRM practices to enhance relationships with their customers; the customers are also likely to be committed to maintaining the relationship with that organization, thereby resulting to Retention. The study further recommends effectiveness of communication between the service provider and the consumer as it is very essential in influencing the trust that customers develop in the firm, their satisfaction with that firm and subsequently their retention in the firm. The study also recommends that an organization reciprocates to its 
customers as it is also likely to retain them. Finally, the study recommends that firms should ensure customer satisfaction as it is a good predictor of future purchase behaviour, an indication of customer retention. Satisfied customers generate profits because they are responsible for a large percentage of sales and are less costly to develop than new customers. Rapid improvements in information technology allow mobile phone providers and their frontline staff to track customer characteristics more easily and respond with appropriate marketing offers.

\section{REFERENCES}

Adrian Payne \& PennieFrow (2005), “A Strategic Framework for Customer Relationship Management”. Journal of Marketing Vol. 69 ,pp 167-176.

Ahn, J.H., Han, S.P., and Lee. U.S. (2006), “Customer churn analysis: Churn determinants and Andaleeb, S. S. (1996). An Experimental Investigation of Satisfaction and Commitment

Anderson, E. and Sullivan, M.W. (1993).The Antecedents and Consequences of Customer Satisfaction for Firms. Marketing Science, Vol. 12(2), pp. 125-43.

Anderson, E., Fornell, C., and Lehmann, D. R. (1994). Customer Satisfaction, Market Share, and Profitability: Finding from Sweden. Journal of Marketing, 58(July), pp.53-66.

Anderson, E., Fornell, C., \& Rust, R. (1997). Customer Satisfaction, Productivity, and Profitability: Differences between goods and services. Marketing science, 16(2),129-145.

Ang, L. and Buttle, F. (2006). Customer retention management processes - a quantitative study. European Journal of Marketing. 40(1/2): 83-99.

Antreas D.A. andOpoulos AI (2003). Modeling customer satisfaction in telecommunication: Assessing the multiple transaction points on perceived overall performance of the provider. Product Operational Management, 12(2): 224-245.

Arora, K.C. (2007). Total Quality Management. New Delhi: S. K. Kataria\& Sons.

Babbie, E. (2011). The Basics of Social Research (5th ed.). Belmont, California, USA: Cengage Learning.

Bagozzi, Richard P. and Youjae Yi (1988), "On the Evaluation of Structural Equation Models," Journal of the Academy of Marketing Science, 16 (Winter), 74-94.

Baron, R. M., \& Kenny, D. A. (1986). The moderator-mediator variable distinction in social psychological research: Conceptual, strategic, and statistical considerations. Journal of Personality and Social Psychology, $51,1173-1182$

Barsky, J. (1995), World-Class Customer Satisfaction, Irwin Professional, Burr Ridge, IL.

Bateson and Hoffman (2002), Essentials of Service Marketing: Concepts and Cases

Berry, W. D., \& Feldman, S. (1985). Multiple Regression in Practice. Sage University Paper Series on Quantitative Applications in the Social Sciences, series No. 07-050). Newbury Park, CA: Sage.

Besterfield, D.H. (1994), Quality Control, Prentice-Hall, Englewood Cliffs, NJ.

Bill Karakostas, DimitrisKardaras, Eleutherios Papathanassiou (August 2004), "The state of CRM adoption by the financial services in the UK, an empirical investigation”. Science Direct, Information and management 42 p853-863.

Bolton, R.N. \& Drew, J. (1991). A multistage model of customers' assessments of service quality and Value. Journal of consumer research, 17(4), 875-884.

Boulding, William, Ajay Kalra, Richard Staelin, and Valarie Zeithaml (1993), “A Dynamic Process Model of Service Quality: From Expectations to Behavioral Intentions, “Journal of Marketing Research, 30 (February), $7-27$.

Brown S.A. and Gulycz, M. (2001).Customer relationship management: A strategic imperative in the world of ebusiness: New York: Wiley.

Bult, Jan Roelf and Tom Wansbeek (1995), “Optimal Selection for Direct Mail,” Marketing Science, 14 (4), 378 95.

Buttle, F. (2004). Customer Relationship Management: Concepts and Tools. Elsevier: Oxford.

Castillo et, al (2009). Understanding Qualitative and Quantitative Research Paradigms

Chakrabarty, S., Whitten, D. \& Green, K.(2007). Understanding Service Quality and Chang, Tung-Zong and Albert R. Wildt. (1994). "Price, Product Information, and Purchase Intention: An Empirical Study," Journal of the Academy of Marketing Science,22(1): 16-27.

Choi TY, Chu R, (2001). Determinants of hotel guests" satisfaction and repeat patronage in Hong Kong hotel industry. Int. J. Hosp. Manage., 20: 277-297.

Churchill, G. A., and Surprenant, C. (1982).An Investigation into the Determinants of Consumer Satisfaction. Journal of Market Research, Vol. 19, pp. 491-504.

Cohen, J., \& Cohen, P. (1983). Applied multiple regression/correlation analysis for the behavioral sciences. Hillsdale, NJ: Lawrence Erlbaum Associates, Inc.

Cooper and Schindler (2003; 2007) Business Research Methods (10th ed.). New York: McGraw- Hill Irwin

Coviello, N.E., Brodie, R.J., Danaher, P.J. and Johnston, W.J. (2002). How firms relate to their markets: An 
empirical examination of contemporary marketing practices. Journal of Marketing. 66(3): 33-46.

Creswell, J. W. (2003). Qualitative, quantitative, and mixed methods approaches (2nd ed.). Thousand Oaks, CA: Sage.

Cronin, J. and Taylor, A. (1992).Measuring service quality: A re-examination and extension. Journal of Marketing, 56: $55-68$.

Cronin, J., \&Taylor, S. (1994). SERVPERF versus SERVQUAL: Reconciling performance-based and perceptions-minus-expectations measurement of service quality. Journal of Marketing, 58(1), 125-131.

Crosby, Lawrence A., Kenneth R. Evans, and Deborah Cowles(1990), “Relationship Quality in Services Selling: An Interpersonal Influence Perspective,” Journal of Marketing, 54 (July), 68-81.

Dall'OlmoRiely et al (1997), "The Variability of Attitudinal Repeat- Rates", International Journal of Research in Marketing, 14, 5, 437-450.

Deighton, John (2000), “Frequency Programs in Service Industries, "in Handbook of Services Marketing and Management, T. Swartzand D. Iacobucci, eds. London: Sage Publications, 401-408.

Dick, Alan S. and Kunal Basu (1994), “Customer Loyalty: Towardan Integrated Conceptual Framework,” Journal of the Academy of Marketing Science, 22 (Spring), 99-113.

Djiofack, Z., C. and Keck, A. (2009).Telecommunications Services in Africa: The Economic Growth. World Development 37(5): 9.

Dowling, Grahame R. and Mark Uncles (1997), "Do Customer Loyalty Programs Really Work?” Sloan Management Review,38 (Summer), 71-82.

Drèze, Xavier and Stephen J. Hoch (1998), "Exploiting the Installed Base Using Cross Merchandising and Category Destination Programs," International Journal of Research in Marketing, 15 (5), 459-71.

Egan, J. (2001). Relationship Marketing: Exploring Relational Strategies in Marketing, Emmanuel Toili (2011). "Collymore Next Safaricom CEO". Daily Nation.

Fecikova, I. (2004), "An index method for measurement of customer satisfaction”, The TQM Magazine, Vol 16 No. 1, pp. 57-66.

Fournier, Susan and Julie L. Yao (1997), "Reviving Brand Loyalty: A Reconceptualization within the Framework of Consumer-Brand Relationships", International Journal of Research in Marketing, 14, 5, 451-472.

Fournier, Susan, Susan Dobscha and David Glen Mick (1998), "Preventing the Premature Death of Relationship Marketing”, Harvard Business Review, (January-February), pages?

Gay, T. (1990), Social Research Methods. New Delhi: Prentice Hall.

George M. Zinkhan and A. Parasuraman, (2002), "Marketing to and Serving Customers through the Internet: An Overview and Research Agenda" ,Journal of the Academy of Marketing Science No.30; pp 286

Ghavami AO (2006). The Impact of CRM on Customer Retention. Masters Thesis. Lulea University of Technology. Grönroos, C. (2004). The Relationship Marketing Process: Communication, Interaction,

Gruen TW, Summers JO, Acito F, (2000). Relationship marketing activities, commitment, and membership behaviors in professional associations. J. Mark., 64(3): 34-49.

Gupta, S. and Zeithaml, V. (2006). Customer metrics and their impact on financial performance. Marketing Science, 25(6): 718-739.

Gustafsson, A., Johnson, M.D., and Roos, I. (2005), "The Effects of Customer Satisfaction, Hall.

Hair, J. F., Anderson, R. E., \& Tatham, R. L. (1995).Multivariate data analysis with Readings (4 ${ }^{\text {th }}$ Ed.). Engelwood Cliff: Prentice-Hall International.

Hammond, Kathy (1997), Brand Loyalty for Frequently Bought Goods. London Business School: Unpublished $\mathrm{PhD}$ thesis.

Hart et al. (1999), “Are Loyalty Schemes a Manifestation of Relationship Marketing?” Journal of Marketing Management, 15, 6, 541-562.

Herrmann, A., Xia, L., Monroe, K.B., and Huber. F., (2007) "The Influence of Price Fairness on Customer Satisfaction: The empirical test in the context of automobile Purchases. Journal of Product \& Brand Management, Vol. 16 Iss: 1, pp.49 - 58

Hoekstra, Janny C., Peter S.H. Leeflang, and Dick R. Wittink (1999), “The Customer Concept: The Basis for a New Marketing Paradigm," Journal of Market-Focused Management, 4 (1),43-76.

Honts, R. and Hanson, J. (2011). Maximizing customer retention a strategic approach to effective churn management. Accenture White Paper

Hoots, M., (2005). Customer relationship management for facility managers. Journal of Facilities Management, 3(4),346-361

Horne, Suzanne and Steve Worthington (1999), "The Affinity Credit Card Relationship: Can it Really be Mutually Beneficial? ", Journal of Marketing Management, 15, 7, 603-616.

Hunt, K. H. (1977). Conceptualization and Measurement of Consumer Satisfaction(ed.), Cambridge, MA: Marketing Science Institute Information Systems, (Winter 2007-2008), 1-15.

Jacobs, W. and Randy, S. (1999). Measuring Service Quality: A re-examination and extension. Journal of 
Marketing, 56, pp 55-68.

Janiszewski, C. (2009). The consumer experiences. Association for consumer research. University of Florida.

Jean, C. and Jacques, T. (2008). Continuous Improvement in Public Services - A Way Forward, Managing Service Quality, 8(5): 339-349.

Jun Wu (2008) "Customer Relationship Management in Practice: A case study of Hi-tech company from China", Service Systems and Service Management, International Conference, Sch. of Econ. \& Manage. Beijing University of Posts \& Telecommunication, Beijing.

Kanji, G. and Moura, P. (2002), “Kanji’s business scorecard”, Total Quality Management, Vol.13 No. 1, pp. 1327.

Kannan, and Mathew D. Bramlett (2000), "Implications of Loyalty Program Membership and Service Experiences for Customer Retention and Value," Journal of the Academy ofMarketing Science, 28 (Winter), 95-108.

Kano, N. (2007). Guide to TQM in Service Industries. Tokyo: Asian Productivity Organization.

Kapferer, Jean-Noël (1999). Strategic Brand Management. $2^{\text {nd }}$ Edition. London: Kogan Page.

Kerin, R.A., Hartley, S.W., \& Rudelius, W. (2009). Marketing (9th ed.). Boston: McGraw-Hill Irwin.

Kim WG, Han JS, Lee E, (2001). Effects of relationship marketing on repeat purchase and word of mouth. J. Hosp. Tourism Res., 25(3): 272-288.

Kim, B., M. Shi and K. Srinivasan (2001). \Reward programs and tacit collusion, "Marketing Science20(2): 99120

Kim, M.K., Park, M.C., and Jeong, D.H. (2004) “The effects of customer satisfaction and Kivetz, Simonson (2002), "Promotion Reactance: The Role of Effort-Reward Congruity," Journal of Consumer Research, 31 (4), 725 737.

Klemperer, Paul (1995). “Competition When Consumers Have Switching Costs: An Overview with Applications to Industrial Organization, Macro Economics, and International Trade,"

Kopalle, Praveen and Scott A. Neslin (2003). "The Economic Viability of Frequency Reward Programs in a Strategic Competitive Environment," Review of Marketing Science, (accessed April16, 2004), available at http://www.bepress.com/romsjournal/vol1/iss1/art1].

Kothari, C. R. (2007). Research Methodology: Methods and Techniques. New Delhi: WishwaPrakashan.

Kotler P, Keller K, (2006). Marketing Management. 12 ${ }^{\text {th }}$ ed. New Jersey: Pearson Prentice Hall.

Kotler, P. \& Armstrong, G. (2010), "Principles of Marketing", 13th ed. New Jersey: Prentice.

Kritsonis W. A., \& Hurton, L (2008). Practical Application for Educational Research and Basic Statistics. Houston, Texas: National Forum Journals

Kukar-Kinney, M., Xia, L, Monroe, L.B., (2007) “Consumers' perceptions of the fairness

Kumar, V., Andrew, J.P. and Robert, P.L. (2007). How valuable is word of mouth? Harvard Business Review, 85(10): 139-146.

Kuo, Y.F., Wu, C.M. and Deng, W.J. (2009), Computers in Human Behavior, Volume 25, Issue.

Lam T, Zhang H, (1999). Service quality of travel agents: the case of travel agents in Hong Kong. Tourism Manage., 20: 341-349.

Lam, S.Y., Shankar, V., Erramilli, M.K., \& Murthy, B. (2004). Customer value, satisfaction, loyalty, and switching costs: An illustration from a business-to-business service context. Journal of the academy of Marketing Science, 32(3), 293-311.

Larivie're, B. and Poel, D. V. D (2005). Predicting customer retention and profitability by using random forests and regression forests techniques. Expert Systems with Applications. 29 (2): 472484.

Latham, Garry P. and Edwin A. Locke (1991). "Self-Regulation through Goal Setting," Organizational Behavior and Human Decision Processes, 50 (2), 212-47.

Lemon KN, Zeithaml VA, (2001). What drives Customer Equity? Mark. Manage., 10: 20-25.

Lemon, Katherine, Tiffany Barnett White, and Russell Winer (2002). "Dynamic Customer Relationship Management," Journal of Marketing, 66 (January), 1-14

Levesque, Terrence and Gordon H. G. McDougall (1999),Determinants of Customer Satisfaction in Retail Banking, International Journal of Bank Marketing, 14(7), 12-20.

Liu, C. Y. (2009). Customer Satisfaction in the service sector, Tokyo: Asian Productivity Organization.

Lommeruda, K. E. and Sørgard, L. (2003), "Entry in telecommunication: Customer Loyalty.

Louviere, J.J., Hensher, D. A. and Swait, J. (2000).Stated choice methods and applications. New York: Cambridge University Press.

Malhotra, N. K., and Birks D. (2007). Common method variance in IS research: A comparison of alternative approaches and a reanalysis of past research. Management Science, 52,1865-1883. (December) doi:10.1287/mnsc.1060.0597.

Martin-Consuegra, D., Molina, A. and Esteban, A., (2007), “An Integrated Model of Price, McGraw-Hill.

Mihelis, G., Grigoroudis, E., Siskos, Y., Politis, Y., and Malandrakis, Y. (2001). Customer Satisfaction Measurement in the Private Bank Sector, European Journal of Operational Research, 130 (2), pp. 347-360. 
Mike Hoot, (2005) "Customer Relationship Management For Facility Managers", Journal of facilities management, 2005, 3,4 ABO/INFORM Global pg.346.

Morgan, Robert M. and Shelby D. Hunt (1994), “The Commitment-Trust Theory of Relationship Marketing, "Journal of Marketing, 58 (July), 20-38

Naichianas et al (1996) Research Methods in Social Sciences, $5^{\text {th }}$ ed., Arnold, Santa crux

Ndubisi, N., and Chan, K. (2005).Factorail and Discriminant Analyses of the

Underpinnings of Relationship Marketing and Customer Satisfaction. International Journal of Bank Marketing, Vol. 23, No.7, pp. 542-557.

Nokia, (2010) Kenya Telecommunications Sector Performance Review: 1999 2003" Research ICT Africa Report

Nunnally, J. C. (1978). Psychometric Theory. New York: McGraw-Hill

O’Brien, Louise and Charles Jones (1995), “Do Rewards Really Create Loyalty?” Harvard Business Review, 73 (May-June),75-82.

Oliver, R.L. (1988; 1997). Satisfaction: A behavioral perspective on the consumer. New York: McGraw-Hill.

Oliver, R.L. (1993). A conceptual model of service quality and service satisfaction: Compatible goals, different concepts. In T.A. Swartz, D.E. Bowen, \& S.W. Brown (Eds.), Advances in services marketing and Management (pp. 65-85). Greenwich, CT: JAI Press.

Olshavsky, R.W., and Miller, J.A. (1972).Consumer Expectations, Product Performance, and Perceived Product Quality. Journal of Marketing Research, Vol. IX(February), pp. 19-21.

Osborne, J. W., Christensen, W. R., \& Gunter, J. (April, 2001). Educational Psychology from a Statistician's Perspective: A Review of the Power and Goodness of Educational Psychology Research.

Ostrom, A., \& Iacobucci, D. (1995). Consumer trade-offs and the evaluation of services. Journal of Marketing, 59(1), 17-28.

Papper Don and Marth Rogers (2004). “Managing Customer Relationship”, Harvard 3 Business Review”, 77 pp 151-60.

Parasuraman, A., Berry, L.L. and Zeithaml, V.A. (1998). Guidelines for Conduction Service Quality Research, Marketing Research, 2(4): 34-44.

Parker, C., and Mathews, B.P. (2001). Customer Satisfaction: Contrasting Academic and Consumers' Interpretations. Marketing Intelligence and Planning, Vol. 19, No.1,pp. 38-44.

Pedhazur, E. J., (1997). Multiple Regression in Behavioral Research (3 ${ }^{\text {rd }}$ ed.). Orlando, FL:Harcourt Brace.

Peng, Leong Yow \& Wang, Qing (2006). Impact of Relationship Marketing Tactics (RMTs) on switchers and stayers in a competitive service industry. Journal of marketing management, 22, pp 25-59.

Peter Verhoef, (2003), Understanding of Customer Relationship Management Efforts on

Customer Retention and Customer Share Development Pine, Joseph B, and James H. Gilmore (1999),The Experience Economy: Work is Theatre and every Business a Stage, Boston, MA: Harvard Business School Press.

Preacher, K.J., \& Hayes, A.F. (2004).SPSS and SAS procedures for estimating indirect effects in simple mediation models Behavior Research Methods, Instruments, \& Computers, 36, 717-731.

Rahimi.and Gwinner, K. P. (2008). Internet Retail Customer Loyalty: The Mediating

Role of Relational Experience: International Journal of Service Industry Management, Vol. 14 Iss: 5, pp.483 500

Reichheld, F.F. \& Sasser, Jr., W.E. (1990; 1996). Zero defections. Quality comes to services. Harvard Business Review,68(5), 105-111.

Rivie're, B., Cadotte, E.R., Woodruff, R.B and Jenkins, R.C. (2006). Developing zones of tolerance for managing passenger rails services quality, International Journal of Quality and Reliability Management, 24 (1): 7-31.

Robson (2002) Business research methods. Oxford University Press.

Roehm, Michelle L., Ellen Bolman Pullins, and Harper A. RoehmJr. (2002), "Designing Loyalty Building Programs for Packaged Goods Brands,” Journal of Marketing Research, 39 (May), 202213.

Roos, I., Gustafsson, A., \& Edvardsson, B. (2006). Defining relationship quality for customer-driven business development. International Journal of service Industry Management, 17(2), 207-223.

Ryals, L.J. and Knox, S. (2005). Measuring risk-adjusted customer lifetime value and its impact on relationship marketing strategies and shareholder value. European Journal of Marketing. 39 (5/6): 456-472.

Samit Chakravorti (2006) "CRM a Content Analysis of Issues and Best Practices", Journal of Consumer Marketing Vol. No 20 pp 385-398.

Saunders et. al (2000;2007), Research Methods for Business Students $2^{\text {nd }}$ Edition, Financial times/prentice Hall.

Shankar, V., Smith, A., \& Rangaswamy, A (2003). Customer satisfaction and loyalty in online and offline environments. International Journal of Research in Marketing, 20 (2), 153-175.

Sharp, B. and A. Sharp, (1997). Loyalty Programs and Their Impact on Repeat-Purchase Loyalty Patterns. International Journal of Research in Marketing 14 (No. 5), 473-486.

Singh, H. (2006). The importance of customer satisfaction in relation to customer loyalty and retention. UCTI 
Working Paper. Asia Pacific University College of Technology and Innovation, Malaysia.

Sirdeshmukh, Sigh, and Sabol (2002). Understanding the structure of customers' satisfaction evaluations of service Delivery.

Smith, J.B., \& Barclay, D.W. (1997). The effects of organizational differences and trust on the effectiveness of selling partner relationships. Journal of Marketing, 61(1), 3-21.

Soderlund, M., and Rosengren, S. (2008), "Revisiting the smiling service Worker and customer.

Soman, Dilip (1998), “The Illusion of Delayed Incentives: Evaluating Future Effort-Money.

Somekh and Lewin (2005). Research Methods in social Sciences.

Spreng, R. A., \&Mackoy, R. D. (1996). An empirical examination of a model of perceived service quality and satisfaction. Journal of Retailing, 72(2): 201-214.

Spreng, R. A., MacKenzie, S. B., and Olshavsky, R. W. (1996). A Reexamination of the Determinants of Consumer Satisfaction. Journal of Marketing, Vol. 60 (July), pp.15-32.

Sprowls, R.C., and Asimow, M. (1962). A Model of Customer Behavior for the Task Manufacturing Corporation. Management Science, Vol. 8 (3), pp. 311-324.

Stanton, W. J., Michael J. E, and Bruce J. W. (1994) Fundamentals in Marketing. 10th ed.

Stengel, G. (2003). Ten tips for measuring and improving performance. Stengel Solutions.

Stone, M., Woodcock, N., and Machtynger, L. (2000). Customer Relationship Marketing: switching barrier on customer loyalty in Korean mobile telecommunication services"

Sullivian T. J (2001). Methods of Social Research. Fort Worth, TX

Tabachnick, B. G., Fidell, L. S. (2001). Using Multivariate Statistics (4th ed.). Needham Heights, MA: Allyn and Bacon

Teas, F. (1994). Closeness, Strength and Satisfaction: Examining Nature of Relationships between providers of Financial Service and their Retail Customers, Psychology and Marketing, 14 (8): 765790.

Terblanche, N.S. and Hofmeyr, J. (2005). A study of two customer retention measures: the American customer satisfaction index and the conversion model.

Trasorras, R., Weinstein, A. and Abratt, R. (2009).Value, satisfaction, loyalty and retention in professional services. Marketing Intelligence \& Planning. 27 (5): 615-632.

Tseng, Yi Ming (2007). The Impacts of Relationship Marketing Tactics on Relationship Quality in Service Industry. The business Review, Cambrdge, Vol, 7 number 2.

Turel, O., and Serenko, A. (2006), "Satisfaction with mobile services in Canada: An empirical

Turnbull, P., \&Moustakatos, T. (1996) Marketing and investment banking: relationships \& competitive advantage. International Journal of Bank Marketing, 14, 38-49

Uncles, Mark D., Kathy Hammond, Andrew S. C. Ehrenberg and R. E. Davis((1994), “A Replication Study of Two Brand-Loyalty Measures", European.

Wassenaar, V., Andaleeb, S. S. and Conway, C. (2005). Customer Satisfaction in the

Restaurant Industry: An Examination of the Transaction-specific model. Journal of Services Marketing, 20 (1): 311.

Weilbacher, W. M. (1993), Brand Marketing. Linconwood, IL: NTC Books, Ch. 7.

Weiner, B. (1996). An attribution theory of motivation and emotion. New York: Springer-Verlag.

Wiersma W(1995). Research Methods in Education: An Introduction $\left(6^{\text {th }} \mathrm{Ed}\right)$

Winter, T. (1999). An Exploratory study of service Quality In The Malaysian Public Service, International Journal of Quality and Reliability Management, 2007, 24(2): 177-190.

Woo, K. and Fock, H.K.Y. (2004). Retaining and divesting customers: an exploratory study of right customers, at-risk right customers, and wrong customers. Journal of Services Marketing. 18 (3): 187-197.

Wu, D. and Pan, A. (2009). A critical Approach to Examining the Effects of Service

Failures in Customer Relationship: The case of Swedish and U. S. Airlines Journal of Travel Research,7: 35 - 40.

Xia, L., Monroe, K. „\& Cox, J..(2004). "The Price Is Unfair! A Conceptual Framework of Price fairness Perceptions

Zeithaml, V.A., Berry, L.L., and Parasuraman, A. (1996).The behavioral consequences of service quality. Journal of Marketing, 60(2): 31-46.

Zeithaml, Valarie A., Leonard L. Berry, and A. Parasuraman (2000), "The Behavioral Consequences of Service Quality," Journal of Marketing, 60 (April), 31-46.

Zhang, Z. John, Aradhna Krishna, and Sanjay K. Dhar (1999; 2000), "The Optimal Choice of Promotional Vehicles, "ManagementScience, 46 (3), 348-62

Zikmund, W. G., Babin, B.J., Carr, J. C. and Griffin, M. (2010).Business Research Methods (8th Ed.). Canada: SouthWestern, Cengage, Learning Canada. 